\title{
ДУХОВНО-ІНТЕЛЕКТУАЛЬНЕ ВИХОВАННЯ МАЙБУТНІХ ІНОЗЕМНИХ ЛІКАРІВ У ЗАКЛАДАХ ВИЩОЇ МЕДИЧНОЇ ОСВІТИ ЯК ОСНОВА МІЖКУЛЬТУРНИХ ВІДНОСИН
}

\author{
Л. О. Гепенко \\ аспірантка кафедри загальної педагогіки і педагогіки вищої школи \\ Харківського національного педагогічного університету імені Г. С. Сковороди
}

У сфері охорони здоров'я людини можна спостерігати певні зміни, що стосуються відкритого вітчизняного й зарубіжного досвіду лікування пацієнтів, права вибору кваліфікованого лікаря й доступності медичних послуг, незважаючи на те, що вони платні. За таких обставин висуваються певні вимоги до особистості лікаря та його функціональних обов'язків. Як зазначає А. Варданян [1], сучасний лікар має володіти не лише українською мовою, але й іноземними мовами, а це, своєю чергою, забезпечить ознайомлення фахівця й використання ним інноваційних медичних досягнень, отриманих у різних країнах. Доцільно зазначити, що таку думку висловлюють й інші дослідники, котрі звужують проблему до вивчення лікарями іноземних мов. У нашому дослідженні дотримуємося іншої точки зору — міжкультурна вихованість лікаря $€$ поняттям ширшим, аніж його комунікативна й мовленнєва компетенції у виконанні професійних обов'язків. Феномен міжкультурної вихованості медичних працівників означає їхню здатність сприймати та розуміти потреби людини незалежно від іiї приналежності до релігії, звичаїв, традицій іншої країни, будувати міжособистісні взаємини на засадах довіри й партнерства, створювати спільні проекти, спрямовані на поліпшення діагностування й лікування пацієнтів.

На нашу думку, міжкультурні відносини у студентському колективі будуються на основі духовно-інтелектуальної вихованості суб'єктів освітнього процесу. По суті, їхня суб'єктність і полягає в тому, настільки розвинений інтелект людини та іï духовний світ.

На практиці спостерігаємо такі тенденції:

- Лікарі розуміють значущість міжкультурного виховання, проте в професійній діяльності не акцентують увагу на проблемі міжкультурної комунікації і на засобах iï здійснення, не завжди виявляють міжкультурну толерантність у професійних ситуаціях, недостатньо активні в пошуках способів міжкультурного спілкування, а також співробітництва на партнерських засадах.

- У професійній діяльності бракує духовно-інтелектуальної вихованості лікарів, спрацьовують корисливі цілі й матеріальне заохочення. Не завжди виявляються такі норми моралі, як совість, доброчесність, обов'язок, гідність, авторитет, етична поведінка.

- У закладах вищої медичної освіти (ЗВМО) недостатньо приділяється уваги духовно-інтелектуальному розвитку здобувачів вищої освіти як основи міжкультурних відносин у студентському колективі.

На основі опрацьованого матеріалу зазначимо, що існує низка досліджень, присвячених формуванню професійних компетентностей майбутніх лікарів, зокрема професійно-мовленнєвої компетентності (А. Варданян) [1], міжкультурної комунікативної компетентності іноземних студентів (Н. Калашнік, Т. Пилип) [3; 8], полікультурної компетентності студентів-медиків (А. Щербакова) [12]. Проте праць, у яких розкривалися б шляхи формування міжособистісних компетентностей майбутніх лікарів як вітчизняних, так і іноземних студентів недостатньо. На нашу думку, саме в процесі міжкультурного виховання студентів формуються такі компетентності.

У статті Л. Гепенко та Л. Рибалко [10] певним чином доводиться ідея такої складової професійної підготовки майбутніх лікарів, як міжкультурне виховання в студентському колективі. Однак автори не закцентували увагу на зв'язки духовно-інтелектуального потенціалу майбутніх іноземних лікарів з побудовою міжособистісних стосунків.

Слід зазначити схожі за змістом праці вчених І. Волошанської, А. Леснянської-Дощак, С. Пілішек, 3. Хало, О. Юзьвяк [7; 9; 11], у яких ідеться про потреби міжкультурного виховання молоді в Німеччині, необхідності співіснування людей різного етнічного походження, зокрема тих, хто навчається. У працях вживається термін «міжкультурне виховання» як ставлення молоді до інших людей, так званих «чужих». Учених об'єднує думка про те, що головною складовою міжкультурного виховання $є$ відносини між учасниками освітнього процесу різних національностей на партнерських засадах, що вибудовуються завдяки міжкультурним зв'язкам. Поняття «міжкультурні зв’ язки» дослідники трактують як своєрідність і незвичайність, ідентичність і відмінність, стандартність і новизну в поглядах, почуттях, розумінні потреб кожної людини, котрі відбиваються у власних кодексах, конвенціях, формах повсякденної поведінки. Міжкультурними, як на думку науковців, будуть такі стосунки між людьми, за яких стирається культурна окремішність і долаються межі різних систем виховання та стереотипних поглядів.

У дослідженні Вей Чжеюань [2] зазначено, що в європейському просторі вживаються терміни як «полікультурне виховання», так і «міжкультурне виховання». Зміст першого терміна пов'язують зі ставленням на 
державному рівні до національних меншин й етнічних груп, котрі проживають на території певної країни, а також гарантуванням їм прав на вивчення рідної мови, збереження власної культури й традицій. Зміст іншого терміна розглядають як процес забезпечення виховання толерантної людини, здатної до комунікації та співпраці з представниками інших культур на засадах партнерства й розуміння потреб кожної людини.

У нашому розумінні міжкультурне виховання майбутніх лікарів $є$ процесом розкриття їхнього професійного й особистісного потенціалу завдяки різним культурам, засвоєння вітчизняними й іноземними студентами досвіду співпраці й партнерства в медичній сфері, формування здатності обмінюватися передовими ідеями діагностування й лікування хворих, об’єднуватися й створювати інноваційні світові технології подолання захворюваності людини.

На основі аналізу наукових праць (Вей Чжеюань, Д. Данко, І. Козубовська) виокремимо такі складники міжкультурного виховання майбутніх лікарів, як міжкультурна комунікація, міжкультурна толерантність, міжкультурна ідентичність. Так, у статті Д. Данко та І. Козубовської [5] обгрунтовуються потреби формування готовності іноземних студентів до міжкультурної комунікації, зазначається, що навчання іноземних студентів має певну специфіку й викликає проблеми, наприклад, мовний бар'єр, недостатній рівень обізнаності щодо особливостей та закономірностей становлення українського соціуму. Результати аналізу свідчать про те, що міжкультурна комунікація є більш грунтовною проблемою й не обмежується лише мовною проблемою. Сутність проблеми полягає в тому, що при діловій зустрічі представників різних культур не завжди усвідомлюють свої культурні стереотипи та установки, вважають свої погляди усталеними й «нормальними», не поступаються один одному і не беруть до уваги такі ж погляди інших людей. У такому випадку комунікантам складно знайти спільну робочу мову.

Нам імпонує думка науковців щодо пояснення змісту готовності студентів до міжкультурної комунікації у складі таких компонентів, як позитивна установка на співробітництво й формування довірливих робочих стосунків у процесі комунікативної взаємодії; знання про свою та іншу культуру, традиції, особливості вербального й невербального спілкування комунікантів; уміння ефективної комунікативної взаємодії, котрі забезпечуються сформованими особистісними й професійними якостями фахівців.

У межах пілотного експерименту студентам першого курсу ХНМУ спеціальностей «Стоматологія» та «Фізична терапія. Ерготерапія» (загальна кількість 54 особи) було запропоновано питання, на які отримали відповіді різного характеру.

1. Чи готові Ви у майбутньому співпрацювати з іноземними колегами?

1) не готовий, не вбачаю у цьому потреби, оскільки надаю перевагу вітчизняним досягненням - 47 \%;

2) цілком готовий, адже в міжнародному партнерстві вбачаю подальший розвиток теоретичної і практичної медицини - $32 \%$;

3) готовий, але мені бракує знань з іноземних мов, що заважає вільному міжкультурному спілкуванню - $21 \%$.

2. Які чинники, на Вашу думку, сприяють готовності лікаря до міжнародного співробітництва й партнерства?

1) внесення у робочі програми 3 навчальних дисциплін суспільно-гуманітарного циклу питань 3 міжнаціонального виховання, проведення відповідних позааудиторних заходів - 49 \%;

2) мені це не цікаво, тому що не збираюся працювати за кордоном - 32 \%;

3) відкритість і комунікативність особистості, довіра й розуміння іншої людини - $19 \%$.

3. Якби Ви знали більше про культуру, мову, релігію, традиції інших народів, то Ваше ставлення до них:

1) змінилося б у кращий бік, бо ці знання розширили б моє уявлення про традиції інших народів - 43 \%;

2) не змінилося б взагалі, бо маю власні переконання, які не збираюся змінювати - 39 \%;

3) змінилися б у гірший бік, бо вони суттєво відрізняються від моїх, а мене це дратує - $18 \%$.

4. Чи були Ви свідком конфлікту між студентами з різних країн? Якщо так, яка Ваша точка зору щодо розв’ язання вказаних конфліктів?

1) не замислювався над цим питанням, бо не був свідком вказаних конфліктів - 52 \%;

2) конфліктів можна уникати, виховуючи толерантне ставлення до представників різних країн - $31 \%$;

3) будь-які конфлікти виникають через особисту невихованість, тому в першу чергу треба підвищувати рівень загальної культури - $17 \%$.

Після проведення бесіди зі студентами «Народні звичаї і обряди українців» студентам запропонували відповісти на питання:

5. Чи готові Ви запросити на традиційне сімейне свято студентів-іноземців?

1) ні, не готовий,бо вважаю, що сімейні свята повинні проходити у вузькому сімейному колі і не збираюся порушувати цю традицію - $47 \%$;

2) так, готовий, із задоволенням поспілкуюся з гостями, поясню значення традиційних символів народних свят - $28 \%$;

3) так, якщо дуже добре їх знаю тому, що не звик запрошувати незнайомих людей до себе додому — 25 \%. 
Аналіз результатів проведеного анкетування засвідчив, що майбутні лікарі недостатньо орієнтовані на міжнародне співробітництво, не завжди розуміють практичну значущість ділових контактів і партнерства в розв'язанні складних професійних завдань.

Учені Г. Кардашевська та О. Мовчан розглядають питання необхідності формування міжкультурної толерантності як важливої складової професійного становлення особистості майбутнього фахівця-лікаря. На думку дослідників, міжкультурна толерантність має передбачати терпиме ставлення лікаря до всіх типів людей, 3 якими вони взаємодіють у професійній комунікації. Відмінності в культурі не узагальнені в правила і тому в «професійному спілкуванні лікаря культурні помилки набувають особливого значення, бо можуть спричинити не лише труднощі в спілкуванні, але й стати причиною погіршення стану хворого, зниження ефективності лікування» [4, с. 41].

Міжкультурна ідентичність - це здатність майбутніх лікарів інтегрувати знання й зразки поведінки колег іншої культури, запозичати кращі приклади професійного розв'язання складних лікувальних справ, будувати професійну діяльність на принципах плюралізму мислення та усвідомлення історичних і культурних процесів [8].

Викладаючи в ЗВМО навчальні дисципліни «Українська мова за професійним спрямуванням» та «Українська мова», зазначимо, що їхній матеріал $є$ сприятливим і доцільним для духовно-інтелектуального розвитку майбутніх іноземних лікарів як основи міжкультурних відносин. Так, святкування Дня української писемності та мови є потужним виховним заходом для порівняння традицій українського народу з традиціями інших країн. Спеціально проведена нами робота була спрямована на формування культури, успадкування духовних надбань українського народу, формування історичної пам'яті. Одним з таких заходів стало «Свято українського Слова». У рамках підготовки до цього свята студенти ознайомилися з історією Дня української писемності та мови, із життєвим шляхом Нестора Літописця, знайшли відомості про «щирого цінителя українського слова» - Петра Яцика. Також були зроблені історичні розвідки з питань історії походження української мови, виникнення української писемності та двох різновидів слов'янських писемних знаків.

Логічним продовженням свята стало виконання вітчизняними студентами (спеціальність «Стоматологія» та «Технології медичної та лабораторної діагностики») творчого завдання: «У повісті «Музикант» Т. Шевченко писав:《Я страшенно люблю дивитися на щасливих людей, i, по-моєму, немає прекраснішого, немає чарівнішого видовища, як образ щасливої людини». Напишіть твір-роздум: «Чи можна бути щасливим, коли ллються сльози матерів...»

На заняттях з іноземними студентами були проведені літературні читання творів Т. Г. Шевченка. Студенти-іноземці самі декламували уривки з творів видатного письменника, а також мали можливість почути вірші у виконанні викладачів та вітчизняних студентів.

Вивчаючи українську мову, студенти-іноземці з перших занять знайомляться з культурою привітання, вчаться коротко розповідати про себе, свою родину, свою країну. У подальшому, набувши досвіду, вони будують діалоги, складають невеликі тексти різноманітної тематики. Лексична складова включає такі теми: «Моя сім'я», «В університеті», «Мій робочий тиждень», «Пори року», «Вихідний день», «У магазині».

Вивчення на II курсі розділів «Морфологія» та «Синтаксис. Пунктуація» передбачає подальше ознайомлення студентів із практичними навичками проживання і спілкування у новому для них середовищі. Так багато текстів містять розповіді про види транспорту та способи пересування конкретно по місту Харкову, про сучасні торгівельні центри та місця відпочинку. Розглядаються такі теми: «Подорож», «Хобі», «День незалежності», «Релігійні свята в Україні», «Погода в Україні», «Мій університет». Наприклад, при розгляді теми «Хобі» студенти із задоволенням розповідають про свої захоплення, ілюструють свої розповіді фотографіями. А ось при вивченні теми «Релігійні свята в Україні» треба заздалегідь відчути настрої групи, тому що не всі студенти толерантно ставляться до інших релігій.

Практичні завдання включають вправи, що ознайомлюють іноземних студентів із народним календарем українців, звичаями й обрядами, назвами одягу, взуття, рослин, тварин, страв, грошових одиниць, продуктів та речей, які можна купити в магазині. Наприклад, під час вивчення теми «Числівник» студенти вчаться правильно відповідати на запитання «Котра година?», адже вживання у цій відповіді порядкових і кількісних числівників відрізняється від російської мови. Також студенти мають нагоду познайомитися з короткими відомостями про життя і творчість українських письменників, таких як Т. Шевченко, Леся Українка, I. Франко, В. Симоненко, Л. Костенко, В. Сосюра, а також із уривками їхніх творів.

Дуже цікавим, з погляду здобувачів вищої освіти, $є$ заняття з теми «Публічний виступ». Готуючись до цього заняття студенти самостійно обирають тему, що стосується української мови, літератури, медицини або їх поєднання, наприклад тема «Письменники-медики». Під час підготовки студенти звертають увагу на такі елементи:

- формування (для себе) основної ідеї виступу;

- визначення необхідності повідомлення;

- попереднє укладання робочого плану; 
- збір матеріалу і його логічна побудова;

- пошук форми повідомлення;

- підготовка технічних засобів та наочних посібників;

- репетиція виступу, що допомагає зробити його цікавим, змістовним і набути навичок, котрі обов'язково знадобляться у подальшому навчанні.

Отже, у дослідженні уточнено термін «міжкультурне виховання» як процес розкриття професійного й особистісного потенціалу завдяки різним культурам, засвоєння вітчизняними й іноземними студентами досвіду співпраці й партнерства в медичній сфері, формування здатності обмінюватися передовими ідеями діагностування й лікування хворих, об’єднуватися й створювати інноваційні світові технології подолання захворюваності людини. Реалізовано ідею духовно-інтелектуального розвитку майбутніх іноземних лікарів як основи міжособистісних стосунків. Доведено, що курси «Українська мова за професійним спрямуванням» та «Українська мова» мають потужний потенціал для міжнаціонального виховання і духовно-інтелектуального розвитку майбутніх іноземних лікарів.

Перспективами подальших розвідок є розроблення методичного семінару з питань міжкультурного виховання майбутніх лікарів для інтернів, магістрантів, аспірантів, викладачів.

\section{Література}

1. Варданян А. Формування професійно-мовленнєвої компетентності майбутніх лікарів : автореф. дис. ... канд. пед. наук : спец. 13.00.04 «Теорія і методика професійної освіти». Хмельницький, 2017. 20 с.

2. Вей Чжеюань. Міжкультурне виховання студентів вищих навчальних закладів засобами музики : дис.... канд. пед. наук : 13.00.07. Київ, 2018. 260 с.

3. Калашнік Н. В. Формування міжкультурної комунікативної компетентності у іноземних студентів у вищих медичних навчальних закладах України : автореф. дис. ... канд. пед. наук : спец. 13.00.07 «Теорія і методика виховання». Умань, $2015.20 \mathrm{c}$.

4. Кардашевська Г. Е., Мовчан О. О. Міжкультурна толерантність як одна з найважливіших морально-етичних цінностей майбутнього лікаря // Духовність особистості: методологія, теорія і практика. 2012. № 4. С. 38-43.

5. Козубовська І. В., Данко Д. В. Формування готовності іноземних студентів-медиків до міжкультурного спілкування // Науковий вісник Ужгородського національного університету. Сер. Педагогіка. Соціальна робота / гол. ред. І. В. Козубовська. Ужгород : Говерла, 2017. Вип. 1 (40). С. 136-138.

6. ульбачко К. С. Студенти-медики України у інтеркультурному просторі // Інноваційні тенденції підготовки фахівців в умовах полікультурного та мультилінгвального глобалізованого світу : зб. тез доповідей II Міжвузівської наук.практ. конф. (11 квітня 2017 р., м. Київ). Київ : КНУТД, 2017. С. 138-141.

7. Леснянська-Дощак А., Юзьвяк О. Роль міжкультурного виховання на сучасному етапі розвитку Німеччини // Молодь і ринок. 2011. № 3 (74). С. 133-135.

8. Пилип Т. Структурний аналіз міжкультурної компетентності лікарів-терапевтів // Нова педагогічна думка. 2016. № 2 (86). С. 90-93.

9. Пілішек С. О. Міжкультурне спілкування як складова професійного спілкування іноземною мовою у міжкультурному середовищі // Вісник Чернігівського національного педагогічного ун-ту. Сер. Педагогічні науки. 2016. Вип. 141. C.163-166.

10. Рибалко Л. С., Гепенко Л. О. Міжкультурне виховання як складова професійної підготовки майбутніх лікарів у закладах вищої медичної освіти // Наукові записки кафедри педагогіки. Харків : ХНУ імені В. Н. Каразіна. 2018. № 44. С. $215-224$.

11. Хало 3. П., Волошанська І. В. Досвід Німеччини щодо міжкультурного виховання та його реалізації у вітчизняному навчально-виховному процесі // Педагогічні науки. 2011. Вип. 98. С. 214-218.

12. Щербакова А. В. Формування полікультурної компетентності у студентів-медиків у навчально-виховному процесі вищого медичного навчального закладу : автореф. дис. ... канд. пед. наук : спец. 13.00.04 «Теорія і методика про фесійної освіти». Старобільськ, 2015. 20 с. 